\title{
MEMOIR
}

\section{FINLAY JAMES CAMERON}

Some two or three years ago, Finlay Cameron, F.I.A., F.F.A., F.R.S.E., was the victim of a serious illness which rendered him a semi-invalid. Nevertheless, it was with painful surprise that his numerous friends learned of his death, very suddenly, on 9 April I954 at the age of 74. He had had a distinguished actuarial and insurance career and was popular with all who had known him.

Cameron was the son of Duncan Cameron, a well-known Scottish artist, and was educated, as was also his elder brother, J. C. Cameron, at that famous Edinburgh institution, George Watson's College. Upon leaving school, he entered in the year 1897 the service of the 'Caledonian' Head Office in Edinburgh in the capacity of apprentice, being rewarded for his services by a salary in the region of $£_{15}$ per annum. There he served for eight years, qualifying as a Fellow of the Faculty in 1904. A year later he secured an appointment to the actuarial staff of the old Friends' Provident Institution at its Head Office, which was then, and had been since its formation, situated in Bradford. This was a momentous move for Cameron, for it meant a transfer from the bustling actuarial stream of Edinburgh to a comparative backwater. Moreover, the F.P.I., as it was then familiarly known, was a life office founded by Quakers for Quakers, an office whose opportunities (and desire) for expansion were limited by its own peculiar circumstances. Those were the surroundings in which Cameron lived and worked for many years until in the early part of the first war that able, dynamic personality, Henry Tapscott, came upon the scene as the F.P.I.'s first General Manager. Then were the shackles cast aside, the F.P.I. was thrown open to all, and the great expansion began with the acquisition of the Century Insurance Company of Edinburgh in 1918 . The Head Office was moved to London and Cameron, who had qualified as a Fellow of the Institute in 1911, was appointed Assistant Actuary in 1919, becoming Joint Actuary in 1927 . These various moves were very welcome to Cameron, who threw himself with characteristic energy into the manifold problems associated with the new era; and he was an undoubted success.

Then in 1928 came the news that Cameron had been appointed to the highly important position of General Manager of the 'Caledonian'; and so he returned once more to Edinburgh, this time as the head of the Company which he had first served as a boy more than thirty years before. The event was indeed tinged with romance. And the two brothers both achieved distinction; for J. C. Cameron, who qualified as an F.F.A. in the same year as Finlay, was by that time the Vice-President and Actuary of the 'Great Southern Life' of Houston, Texas.

Finlay was very conscious of his new high responsibility. He was then aged 47. He had no technical knowledge of General Insurance business on a world-wide scale. He brought to bear all his high principles and complete conscientiousness and all his sound actuarial judgment. In due course he served as Chairman of the Associated Scottish Life Offices and as President of the Insurance Society of Edinburgh and, as his crowning achicvement, was elected President of the Faculty in 1942.

Finlay's principal contribution to actuarial thought was a monumental paper 
(perhaps the last in what may be termed the classical style) on non-profit policies submitted to the Institute in I9I 3 ( $(. I . A .48,45)$. When he came to deliver his Presidential Address, he devoted a large part of it to the post-war training of the new generation, in whom he had a profound interest.

For some years before and after his retirement in 1945 he was interested in charitable causes, serving on numerous committees, and was particularly devoted to the Edinburgh Children's Holiday Fund.

On the social plane Finlay was a delightful companion, and his private life was enriched by the pleasure he took in his family and the support and encouragement he received from his charming wife.

G.H.R. 